\title{
Carbon Allowance Allocation on Chinese Industrial Sectors in 2030 under Multiple Indicators
}

\author{
Jianguo Zhou, Baoling Jin* \\ North China Electric Power University, Hebei, China
}

Received: 12 March 2018

Accepted: 26 April 2018

\begin{abstract}
Aiming at China's "2030 target," and given the key role of industrial sectors in $\mathrm{CO}_{2}$ emission reduction, this paper selects the path of allocating carbon emission allowance among different industrial sectors. By selecting $\mathrm{CO}_{2}$ accumulation emissions, the industry-added value and the $\mathrm{CO}_{2}$ emission efficiency which is calculated by the super-SBM model, a carbon intensity distribution model has been established for the allocation. Considering the different preferences of policymakers, different weights are used, meanwhile, an entropy weighting method is proposed to make a contrast. The main conclusions of this paper are:

1) The tendency of decision makers to assign principles has a great impact on the distribution of responsibility for the industry's emission reduction responsibilities.

2) $\mathrm{CO}_{2}$ emission intensity and carbon dioxide emission efficiency of various industries in China are very different, which is mainly related to the energy consumption demand, input, and output of various industries.

3) More historical accumulated emission and carbon intensity will shoulder more intensity reduction burden, and the industrial sector with the heaviest reduction burdens are those with the two high indicators, regardless of the tendency of decision makers.
\end{abstract}

Keywords: industrial sectors, super-SBM model, entropy weighting method, carbon emission allowance

\section{Introduction}

Global warming has been identified as a critical issue in all areas and has attracted worldwide attention. Carbon dioxide, a type of greenhouse gas, is often conceived as the main cause that changes the global climate and threatens human survival [1-4]. According to the Norwegian international center for climate and environmental research, the accumulated carbon

\footnotetext{
*e-mail: 895608564@qq.com
}

emissions of China reached 146.4 billion tons in 2016 - more than the 146.2 billion tons in the United States [5]. As the world's largest energy consumer and carbon dioxide emitter, China promulgated the policy target of reducing carbon intensity during the period of 2020 by $40 \%$ to $45 \%$ based in 2005 . Moreover, at the Paris Climate Conference in 2015, China once again made a commitment to reduce carbon intensity by $60 \%$ to $65 \%$ in 2030 based on the level of 2005 , and vowed to put a peak on its growing $\mathrm{CO}_{2}$ emissions by 2030 [6]. In order to reach the reduction target, the Chinese government is taking effective measures to reduce emissions. In 2013, 
seven cities and provinces began to set up regional carbon emissions to test for a national carbon deal. In 2015, China announced that it had established a carbon emissions trading market in 2017 at a bilateral meeting. In 2018, China will improve relevant legislation on the carbon market, and by 2019 the national carbon trade will finally enter the trial operation [7].

For our purposes, how to allocate the greenhouse gas emission reduction burdens has become one of the most popular and complex issues for domestic and foreign researchers [8]. It is an imperative need to evaluate the effectiveness and equity implications of using different mechanisms to reduce carbon emissions. [9] emphasized that with an increasing public desire to regulate carbon emissions, adopting renewable energy standards and green building codes is an effective measure. [10] estimated China's $\mathrm{CO}_{2}$ emissions in 2002 and 2007 by using a production-based and a consumption-based measure at the sector industry level. [11] drew the carbon flow of China for 2008 to reveal the characteristics of carbon flow and emissions in China, including not only the energy-related carbon emissions, but also the process emission. [12] investigated the policy relevance of strategic partitioning of emission allowances in the context of actual and prospective EU climate policies, simultaneously examining the potential effects of such strategic behavior on compliance cost and emissions prices. [13] assessed the potential of $\mathrm{CO}_{2}$ mitigation in buildings, and investigated the economic factors that determine energy-related $\mathrm{CO}_{2}$ emissions in China's commercial and residential buildings. [14] held the view that the allowance mechanism is one of the core and most sensitive aspects in the design of a carbon emissions trading scheme.

Undoubtedly, the allocation of $\mathrm{CO}_{2}$ emissions may be performed at different levels [15], and the type of allocating $\mathrm{CO}_{2}$ emissions may be classified into three categories. The first category focuses on the allocation among different countries. Based on the principle of "common but differentiated" responsibility, [16] selected eleven proposals that are presently prevailing around the world, and discussed the matter of "equity and justice," which has become one of the most controversial issues in climate debates. [17] presented a carbon Lorenz curve and Gini coefficient to identify potentially unfair use of international aviation carbon emission rights in different countries. By establishing an equitable access to sustainable development model, [18] measured carbon equity after allocating from the global rather than the narrower national perspective. [19] presented an analysis on how effort-sharing approaches affect emission allowances and abatement costs of China and India; the second category concerned allocation among different provinces in China. [20] proposed regional allocation based on equity and development principles, emphasizing equity and development strategies. Given that a fixed national emission reduction target could be achieved by imposing emission quotas among different regions, [21] proposed a novel nonlinear programming approach to investigate the optimal carbon emission quota allocation for China, by developing a performancebased model to measure the opportunity cost of $\mathrm{CO}_{2}$ emission reduction and using a variable coefficient model to simulate carbon dioxide emission abatement cost, then obtain the optimal emission quota. The third category regards allocating $\mathrm{CO}_{2}$ emissions on some specific sectors. By making an in-depth exploration in China's electricity sector and the characteristics of a sector's inner structures, [22] reviewed the factors that related to $\mathrm{CO}_{2}$ mitigation potential and costs. By constructing a mathematical model, [23] investigated the impacts of carbon allowance allocation policy in the transportation industry, it reflected that for the sake of maximizing profits, industry managers should consider different carbon allowance allocation constraint scenarios.

When allocating carbon emissions, considerable research has been advocated and applied by the different principles and allocation criteria. Equity principle has considerable variation in implications of distributive justice, it will be important for decisionmakers to clarify concepts of equity during the course of allocating carbon emissions [24]. [25] deconstructed the general principles of equity into egalitarian, sovereign, horizontal, vertical, and polluter pay equity. In order to arrive at "fair," [36] presented a sectoral approach to burden sharing, and distributed the burden of emission reductions as a limitation of coal use for power production, minimum requirements for renewable energy, and minimum energy efficiency improvement rates in industry. [27] provided an allocation scheme by considering historical emissions and future needs for developed and developing countries simultaneously, and analyzed the peak years and associated abatement costs with different starting years.

Meanwhile, plenty of scholars are interested in allocating the carbon quotas by means of two major approaches of allocation: free allocation and auction. Within a free allocation there are two acceptable ways to allocate carbon quotas: grandfathering and benchmarking. [28] considered the free allocation of emission allowances in a dynamic context and believed that grandfathering schemes which allocate allowances proportionally to past emissions are first-best. [29] derived optimal grandfathering schemes under the condition that relocation is averted with a minimum of transfers to a firm. [30] compared the mechanisms of grandfathering and benchmarking, and held the view that benchmarking can more effectively motivate manufacturers and retailers. [31] analyzed the proposal of "South-North Dialogue," and implied that those approaches were based on the criteria of responsibility, capability, and potential. According to the emission trading policy in Korea, [32] divided the emission trading scheme into two stages in the electricity sector, and found that the auction is the most powerful policy for the initial allocation of emission allowances. 
As for the method of carbon allowance allocation, [33] measured operational efficiency with the Malmquist Index, in which power capacity, coal consumption, and employee number are used as input variables and power generation as the output variables. [34] built a carbon dioxide emissions allocation mechanism based on the radial zero sum gains data envelopment (ZSG-DEA) allocation model, and used the ZSG-DEA model to allocate carbon dioxide emissions between different Chinese provinces. [35] applied the inputoutput model to explain the relationship between China's inter-regional spillover of carbon dioxide emissions and domestic supply chains for 2002 and 2007.

Traditional $\mathrm{CO}_{2}$ emission allocation is generally focused on the distribution of different regions and the geographical location [36, 37]. This kind of allocation problem arises mainly from two angles, one is the international distribution of responsibility between different countries, the other is among the different provinces. There is little research on the distribution of emission reduction responsibilities between different industries from the perspective of a country's industry. Undoubtedly, industry is the main source of energy and resource consumption and pollutants in the country, while meanwhile it seriously impedes sustainable development. In this sense, a necessary but changeable step is to reach a consensus on the responsibility sharing of $\mathrm{CO}_{2}$ emission reductions among different industry sectors. In different terminal sectors, related carbon dioxide reduction policies should be targeted, for the reason that the main carriers of $\mathrm{CO}_{2}$ flow are different [38]. Therefore, it is critical to investigate the influence of factors of $\mathrm{CO}_{2}$ emissions changes in the major industries so as to provide recommendations for policy makers.

In this paper, we propose a new perspective on the allocation of carbon dioxide emissions by decomposing the national emission reduction target into industrial sectors by illustrating the super-SBM model dealing with undesirable outputs to measure the emission efficiency of carbon dioxide. Simultaneously, it must be based on the principles of egalitarianism, equity, and efficiency in order to construct a comprehensive index and analyze the strategies of carbon dioxide emissions at industry sectors. This will provide a reference and basis for a future national allowance allocation at the sector level.

\section{Material and Methods}

\author{
Indicator Selection
}

We select accumulated carbon dioxide emissions, industrial added value, and carbon dioxide emissions efficiency as indicators for emission reduction responsibility, capacity, and potential, respectively, to quantify the burdens each industry might shoulder (Table 1).

\section{The Assumptions of the Model Are as Follows}

\section{Responsibility}

As we all know, the more historical cumulative emissions of carbon dioxide industry, the greater contribution to the global greenhouse, and they should bear the responsibility [39-41]. Since the climate negotiations, the international community has had a heated discussion on the issue of allocating responsibility for emission reduction and the issue of equitable distribution of carbon dioxide emission rights. In particular, the principle of fairness on the allocation of carbon dioxide emissions refers to how every industry should have equal rights of carbon dioxide emissions. In addition, the industries that have accumulated more carbon dioxide in history will contribute more to global warming, so the greater the burden of reducing emissions they should bear.

\section{Capacity}

Carbon intensity control of industrial sectors need to adjust the energy structure, improve the efficiency of energy consumption, introduce new technology, and so on, it will need a lot of money. In practice, the economy and emissions capital investment ability are varied from industries. Particularly, the capacity principle is on behalf of the ability of industry funds to undertake the costs of reducing emissions while

Table 1. Intensity reduction allocation principles and indicator selection.

\begin{tabular}{|c|l|c|c|}
\hline Indicator & Principle & Interpretation & Dimension \\
\hline $\begin{array}{c}\text { Historical accumulated } \\
\text { carbon dioxide } \\
\text { emission }\end{array}$ & Egalitarian & $\begin{array}{c}\text { The more the industry accumulates carbon dioxide emissions, the greater } \\
\text { the contribution to the greenhouse effect, the greater the responsibility for } \\
\text { reducing emissions }\end{array}$ & Responsibility \\
\hline $\begin{array}{c}\text { Industrial } \\
\text { added value }\end{array}$ & Vertical & $\begin{array}{c}\text { The greater the value added value of the industry, the stronger } \\
\text { the economic emission reduction ability, and the greater the burden } \\
\text { of emission reduction. }\end{array}$ & Capacity \\
\hline $\begin{array}{c}\mathrm{CO}_{2} \text { emission } \\
\text { efficiency }\end{array}$ & Efficiency & $\begin{array}{c}\text { The lower the efficiency of } \mathrm{CO}_{2} \text { emission in the industry, the more } \\
\text { unfavorable the control of the national emission intensity }\end{array}$ & Potential \\
\hline
\end{tabular}


Table 2. Conversion coefficient and $\mathrm{CO}_{2}$ emissions conversion coefficient of different kinds of energy.

\begin{tabular}{|c|c|c|c|}
\hline Energy & Statistical unit & Conversion coefficient & $\begin{array}{c}\mathrm{CO}_{2} \text { emissions conversion coefficient } \\
(\mathrm{C} /(\mathrm{t} / \mathrm{t}))\end{array}$ \\
\hline Coal & million ton & $0.7143 \mathrm{kgce} / \mathrm{kg}$ & 0.747 \\
\hline Coke & million ton & $0.9714 \mathrm{kgce} / \mathrm{kg}$ & 0.855 \\
\hline Crude oil & million ton & $1.4286 \mathrm{kgce} / \mathrm{kg}$ & 0.585 \\
\hline Gasoline & million ton & $1.4714 \mathrm{kgce} / \mathrm{kg}$ & 0.553 \\
\hline KeroSne & million ton & $1.4714 \mathrm{kgce} / \mathrm{kg}$ & 0.571 \\
\hline DieSl oil & million ton & $1.4571 \mathrm{kgce} / \mathrm{kg}$ & 0.592 \\
\hline Fuel & million ton & $1.4286 \mathrm{kgce} / \mathrm{kg}$ & 0.618 \\
\hline Natural gas & billion cubic meters & $1.2721 \mathrm{kgce} / \mathrm{m}^{3}$ & 0.448 \\
\hline Power & billion kwh & $0.1229 \mathrm{kgce} /(\mathrm{kwh})$ & 1.814 \\
\hline
\end{tabular}

ensuring their own stable development. Different industries have different economic backgrounds and outputs, and the added value of its representing the industry to create new value in the process of production operation also represents industry's contribution to the gross domestic product (GDP). More value-added industries will be more capable of cutting emissions, and the feasibility of reducing emissions will be higher [42-44].

\section{Potential (CO, Emissions Efficiency 2005)}

$\mathrm{CO}_{2}$ emissions efficiency is for the dimension of reduction potential, which means one industry with high $\mathrm{CO}_{2}$ emissions efficiency has more room to increase the emission reduction efforts. In contrast, the lower the efficiency of $\mathrm{CO}_{2}$ emission in the industry, the greater the responsibility for $\mathrm{CO}_{2}$ emissions reduction. It can also be understood as carbon resource configuration optimization principle, reflecting the principle of coordinated development of economy and environment - namely the limits on emissions of $\mathrm{CO}_{2}$ limited space, as much as possible in order to obtain the biggest economic output. With global environmental problems, the greenhouse effect has caused especially widespread concern, and different scholars have proposed different methods or indicators to evaluate the efficiency of $\mathrm{CO}_{2}$ emissions. [45] introduced a concept of industry $\mathrm{CO}_{2}$ emissions efficiency and relative design and industry $\mathrm{CO}_{2}$ emissions coefficient to measure it. Based on the stochastic non-radial model, [46] evaluated energy efficiency, $\mathrm{CO}_{2}$ emissions efficiency, energy-saving potential, and $\mathrm{CO}_{2}$ emissions reduction potential in China. [47] applied an inseparable input-output measure model to analyze eight container ports with $\mathrm{CO}_{2}$ emissions in China.

\section{Estimation of Carbon Emissions}

In the process of production, coal, carbon, oil, and other energy inputs inevitably lead to emissions of carbon dioxide and other pollutants. We employ the normalized approach recommended by the Intergovernmental Panel on Climate Change in the IPCC guideline to assess China's $\mathrm{CO}_{2}$ emissions [48], which can be calculated according to the following Eq. 1:

$$
C O_{2}=\sum_{i=1}^{9} E_{i} * K_{i} * M_{i} * \frac{12}{44}
$$

...where $\mathrm{i}$ indicates different fossil fuels, including coal, coke, crude oil, gasoline, kerosene, diesel oil, fuel, natural gas, and power. $\mathrm{E}_{\mathrm{i}}$ represents total consumption of different kinds of energy; $\mathrm{K}_{\mathrm{i}}$ and $\mathrm{M}_{\mathrm{i}}$ represent conversion coefficient and $\mathrm{CO}_{2}$ emissions conversion coefficient, respectively; and parameter $12 / 44$ is the ratio between the mass of one carbon atom and the mass of one carbon dioxide molecule. As shown in Table 2.

\section{Super-SBM Models}

As an environmental pollutant, carbon dioxide is the undesired output generated by industry to obtain the desired output. There's discrepancy between industries at energy consumption demand, production technology, production process, and carbon dioxide emissions. [49] evaluated the unified efficiency of China's industrial sector by applying a non-radial DEA model. [50] proposed an improved super-SBM model dealing with undesirable outputs, and measured energy efficiencies of various industrial sectors in China. The super-SBM model has the high discriminating ability for further ranking the efficient DMUs that are particularly suitable for dealing with $\mathrm{CO}_{2}$ emissions [51, 52] constructed the calculation model based on slack variable (slacksbased measure, SBM). The slack variable directly into the objective function formed a kind of radial, and the angle of efficiency measurement method can avoid radial deviation and the selection of angle difference. [53] held the view that slack is often not captured by 
the directional technology distance function; however, it is an important source of inefficiency. [54] put forward the SBM model, and solved the problem of slack variable with the expected output, and the model in the ecological efficiency and environment efficiency evaluation quickly got a large number of applications and showed good character and credibility.

Supporting a production system with $n$ DMUs, each unit has three factors: inputs, desirable outputs, and undesirable outputs, as represented by three vectors: $\mathrm{X}$, $Y_{g}, Y_{b}$.

Respectively, $X=\left[x_{1}, x_{2}, \ldots, x_{n}\right], Y_{g}=\left[y_{1}^{g}, y_{2}^{g}, \ldots\right.$ ., $\left.\mathrm{y}_{\mathrm{n}}^{\mathrm{g}}\right]$, and $\mathrm{Y}_{\mathrm{b}}=\left[\mathrm{y}_{1}^{\mathrm{b}}, \mathrm{y}_{2}^{\mathrm{b}}, \ldots, \mathrm{y}_{\mathrm{n}}^{\mathrm{b}}\right]$, and the super-SBM model dealing with undesirable outputs for evaluating DMU is as follows:

$$
\begin{aligned}
& \min \rho^{*}=\frac{1+\frac{1}{m} \sum_{i=1}^{m} \frac{s_{i}^{-}}{x_{i}}}{1-\frac{1}{s_{1}+s_{2}}\left(\sum_{r=1}^{S_{1}} \frac{s_{r}^{g}}{y_{r}^{g}}+\sum_{t=1}^{S_{2}} \frac{s_{t}^{b}}{y_{t}^{b}}\right)} \\
& \text { s.t. } \quad x_{i} \geq \sum_{j=1, \neq 0}^{n} x_{i j} \lambda-s_{i}^{-} \\
& y_{t}^{b} \geq \sum_{j=1, \neq 0}^{n} y_{t j}^{b} \lambda-s_{t}^{b} \\
& 1-\frac{1}{s_{1}+s_{2}}\left(\sum_{r=1}^{s_{1}} \frac{s_{r}^{g}}{y_{r}^{g}}+\sum_{t=1}^{s_{2}} \frac{s_{t}^{b}}{y_{t}^{b}}\right)>0 \\
& s^{-}, s^{g}, s^{b}, \lambda \geq 0 \quad i=1,2 \ldots, m \quad r=1,2, \ldots, q \quad j=1,2, \ldots, n
\end{aligned}
$$

...where $\lambda$ is the intensity vector; $s=\left(s^{-}, s^{g}, s^{b}\right)$ corresponds to the slacks in inputs, desirable outputs and undesirable outputs; $\mathrm{m}, s_{1}$, and $s_{2}$ stand for the number of factors for inputs, desirable outputs, and undesirable outputs; and the optimization function value of $\rho^{*}$ is the efficiency value of the decision-making unit $\left(x_{i k}, y_{r k}{ }^{g}, y_{r k}{ }^{b}\right)$. The efficiency value of the super-SBM model will exceed 1 , which can overcome the defect that cannot be compared with the efficiency of the previous effective unit, and can further accurately compare the effective value of unit efficiency.

This paper uses a panel of 42 industries in China from 2005 to 2015 to investigate the optimal carbon emission quota allocation among industries. Like many previous studies, labor, capital stock, and energy are introduced in the model as input factors, value-added of the industry is used as a sole desirable output, and $\mathrm{CO}_{2}$ emission are used as an undesirable output. [55] evaluated the industrial $\mathrm{CO}_{2}$ emissions efficiency, and emissions for the 30 provinces in China. This indicates that the efficiency of undesired outputs can be calculated by the ratio of the undesired output value to the pre-optimal output value; therefore, we can define $\mathrm{CO}_{2}$ emissions efficiency (Ce) as Eq. 3:

$$
C_{e}=\frac{y_{t j}^{b} \lambda-s^{b}}{y_{t j}^{b}}
$$

\section{Allocation Method for China's Intensity Reduction Target \\ Comprehensive Emission Reduction Index Construction}

The comprehensive index of emission reduction $R_{i}$ is constructed based on the three indicators of capacity, responsibility, and potential, which are quantified by the historically accumulated $\mathrm{CO}_{2}$ emissions, industrial added value, and $\mathrm{CO}_{2}$ emissions efficiency. The higher the value of $\mathrm{R}_{i}$, the more reduction burden an industrial sector needs to shoulder. The index of $\theta_{i}$ is calculated by the following formula:

$$
\theta_{i}=\omega_{1} A_{i}+\omega_{2} B_{i}+\omega_{3} C_{i}
$$

...where $\theta_{i}$ is the comprehensive index for $\mathrm{i}$ industrial sector; $A_{i}$ represents the performance of responsibility allocation indicators under the principle of fairness of the industry (namely the cumulative carbon dioxide emissions of $\mathrm{i}$ industries), and the greater the value in the industry, the greater the burden will be borne; $\mathrm{B}_{\mathrm{i}}$ represents the principle of industry feasibility, namely the value added value of $i$ industries, and the greater the added value of the industry, the greater the burden of emission reduction; on behalf of the principle of responsibility allocation performance indicators, $\mathrm{C}_{\mathrm{i}}$ represents carbon dioxide emissions efficiency, which is calculated by the super-SBM efficiency evaluation model where the smaller the value, on the contrary, the greater the burden the industry may shoulder; i represents 42 industrial sectors of China ( $i=1,2, \ldots, 42$ ); and $\omega_{1}, \omega_{2}, \omega_{3}$ are the weights for the three indicators, representing the tendency of decision makers to assign principles in the allocation plan, and satisfying the equation $\omega_{1}+\omega_{2}+\omega_{3}=1$.

The multi-indicator weighting allocations of eight cases are shown in Table 3.

Case 1, equal weights, considers three allocation principles, and the distribution of three principles gives the same preference.

Table 3. Weights of indicators under four cases.

\begin{tabular}{|c|c|c|c|c|}
\hline Weight & $\omega_{1}$ & $\omega_{2}$ & $\omega_{3}$ & $\omega_{1}+\omega_{2}+\omega_{3}$ \\
\hline Case1 & 0.33 & 0.33 & 0.33 & 1 \\
\hline Case2 & 0.5 & 0.25 & 0.25 & 1 \\
\hline Case3 & 0.25 & 0.5 & 0.25 & 1 \\
\hline Case4 & 0.25 & 0.25 & 0.5 & 1 \\
\hline
\end{tabular}


Case 2, preference for capacity, means the dimensions of capacity in preference to responsibility and potential.

Case 3, preference for responsibility, means that cumulative carbon dioxide emissions are the most important of the three indicators.

Case 4, preference for potential, means that potential is of significance to carbon dioxide intensity reduction target.

\section{Entropy Weighting Method}

Entropy weighting method is a mathematical method to calculate a comprehensive index based on the comprehensive consideration of the information provided by each factor. As an objective comprehensive weighting method, it determines the weight according to the amount of information transmitted to the decisionmaker.

The emission reduction weighting decision making matrix A of the three indicators for the industrial sectors is given as below:

$$
R=\left[\begin{array}{cccc}
r_{11} & r_{12} & \ldots & r_{1 m} \\
r_{21} & r_{22} & \ldots & r_{2 m} \\
\vdots & \vdots & \ddots & \vdots \\
r_{n 1} & r_{n 2} & \ldots & r_{n m}
\end{array}\right]
$$

...where $r_{i j}$ represents the value of indicator $\mathrm{j}$ for industry sector $\mathrm{i}(\mathrm{i}=1,2,3, \ldots, \mathrm{n} ; \mathrm{j}=1,2, \ldots, \mathrm{m})$. Then, due to the different units, normalization is conducted as follows:

$$
c_{i j}=\frac{r_{i j}}{\sum_{i=1}^{n} r_{i j}}
$$

The standardized decision making matrix is as follows:

$$
c=\left[\begin{array}{cccc}
c_{11} & c_{12} & \ldots & c_{1 m} \\
c_{21} & c_{22} & \ldots & c_{2 m} \\
\vdots & \vdots & \ddots & \vdots \\
c_{n 1} & c_{n 2} & \ldots & c_{n m}
\end{array}\right]
$$

The entropy of each indicator can be calculated after standardizing statistical data. The entropy $\mathrm{H}_{\mathrm{i}}$ of the ith indicator can be defined as:

$$
H_{i}=-k \sum_{j=1}^{n} c_{i j} \ln c_{i j}
$$

..where $\mathrm{k}=1 / \ln n$, suppose $\mathrm{c}_{\mathrm{ij}}=0$, then $\mathrm{c}_{\mathrm{ij}} \operatorname{lnc} \mathrm{c}_{\mathrm{ij}}=0$. The weighted entropy value is obtained using the following equation:

$$
\omega_{i}=\frac{1-H_{i}}{m-\sum_{i=1}^{m} H_{i}}
$$

\section{Allocating China's 2030 Intensity Reduction Target}

Based on the comprehensive index in the above section, the carbon intensity reduction burden is quantified for each industry and the allocation model is constructed. The allocation target is based on 60-65\% carbon dioxide emission reduction per unit of GDP from 2005 levels by 2030. In this study, we select $65 \%$ reduction as the example target.

$$
I_{2030}=\beta I_{2005}
$$

The value of $\beta$ is the reduction target in 2030, and it is the residual coefficient representing national carbon intensity after achieving the 2030 reduction target, indicating that the value of China's carbon intensity is $\beta$ times that of 2005; $I_{2030}$ is the carbon intensity of China in 2030 and $\mathrm{I}_{2005}$ is the carbon intensity of China in 2005.

As for each industry, the relationship between the residual coefficient and carbon intensity also exists.

$$
I_{i 2030}=\beta_{i} I_{i 2005}
$$

...where $\beta_{\mathrm{i}}$ is the residual coefficient for each industrial sector, and $\mathrm{I}_{\mathrm{i} 2005}$ and $\mathrm{I}_{\mathrm{i} 2030}$ are the carbon intensities of i industrial sectors in 2005 and 2030, respectively.

The bigger the comprehensive index, the greater the carbon intensity reduction burden that the industrial sector might take. This means that carbon intensity may be reduced to a lower level if the $\beta_{i}$ value is smaller. In addition, since the marginal abatement cost increases, the cost of cutting one more unit of emission rises, and therefore the marginal mitigation burden should diminish. This trend can be manifested by processing the comprehensive index as a natural logarithm form, with the function of $\beta_{i}$ defined as follows:

$$
\beta_{i}=f\left(\theta_{i}\right)=\partial \operatorname{Ln}\left(\theta_{i}^{-1}\right)
$$

The $\mathrm{CO}_{2}$ emission amount of China in 2030 can be expressed by Eqs. (13) and (14):

$$
\begin{gathered}
C E_{2030}=\sum_{i=1}^{n} I_{i 2005} \beta_{i} G D P_{i 2030} \\
C E_{2030}=G D P_{2030} I_{2030}
\end{gathered}
$$

...where $\partial$ is the parameter to be estimated, $\mathrm{CE}_{2030}$ is the $\mathrm{CO}_{2}$ emission amount of China in 2030, and GDP 2030 
and GDP ${ }_{\mathrm{i} 2030}$ are the national and $\mathrm{i}$ industrial sector GDP values in 2030, respectively. From Eq. (10) to Eq. (14), we obtain the mathematical expressions of parameter a as follows:

$$
\partial=\frac{G D P_{2030} \beta I_{2005}}{\sum_{i=1}^{n} \operatorname{Ln}\left(\theta_{i}^{-1}\right) I_{i 2005} G D P_{i 2030}}
$$

Based on the value of $\partial$, we can get the residual coefficient of $\beta \mathrm{i}$, which means that the carbon intensity per unit of GDP in 2030 might be reduced to $\beta$ i times that of 2005. We obtain the carbon intensity value accordingly. If each industrial sector achieves this carbon intensity value, the national carbon intensity reduction target will be met.

\section{Data Source and Processing}

According to the data and processing methods, we calculate the values of three indicators in 42 industrial sectors in China (Table A1). This paper proposes a carbon intensity reduction target allocation method at the industry level in order to provide decision makers with reference information to distribute the mitigation target. The data source and processing method are as follows:

Labor is represented by the number of annual average employees in the industrial sector as sourced from the China Statistical Yearbook and China industrial statistics yearbooks from 2005-2015.

For capital, we utilize the outstanding net value of fixed asset of the enterprises above designated scale as the proxy for capital input. The data are collected from the China Statistical Yearbook.

Energy is the total energy consumption of subindustries as the proxy for energy input. The data are collected from the China Statistical Yearbook.

Desirable output is the industrial added value data (2005-2007) collected from the Chinese Statistical Yearbook. However, since these data are only counted to year 2007, the industrial added value data from 2008 to 2015 are calculated using the officially released annual average growth rate of added values, and the data are from National Bureau of Statistics of China and the China Statistical Yearbook (2005-2007).

Undesirable output data are collected from the National Bureau of Statistics, the China Statistical Yearbook, and the China Energy Statistics Yearbook. Most of the $\mathrm{CO}_{2}$ emitted by the electricity sector is utilized for producing electrical power, therefore, the actual energy consumption of the electricity sector is only the energy consumption corresponding to the selfuse of electricity.

Based on these data, accumulated carbon dioxide emissions of 42 industrial sectors in China from 2000 to 2005, industrial added value of 2005 and $\mathrm{CO}_{2}$ emissions efficiency of 20005 are calculated. Because the units for the three indicators are different, the data cannot be added together directly. We therefore chose a percentage to do the calculation. The descriptive statistical characteristics of the above-mentioned 76 input/output variables are shown in Table 4. This suggests that the median of different indicators is smaller than the mean value, and a larger standard deviation shows the unbalanced production status of different industrial sectors, which is more prominent in terms of desirable outputs and undesirable outputs.

\section{Results and Discussion}

\section{$\mathrm{CO}_{2}$ Efficiency Performance in China's Industrial Sectors}

Spearman's coefficient shows that the DMU production process has some so-called "isotonicity." In addition, the correlation between inputs and undesirable outputs is insignificant, in line with the actual production expectation (Table 5). Therefore, $\mathrm{CO}_{2}$ efficiency measured by the super-SBM model is reliable, and the research results are completely believable.

Table 4. Descriptive statistical characteristics of input and output variables.

\begin{tabular}{|c|c|c|c|c|c|}
\hline \multirow{2}{*}{ Variable } & \multicolumn{3}{|c|}{ Inputs } & \multicolumn{2}{c|}{ Outputs } \\
\cline { 2 - 6 } & $\begin{array}{c}\text { Labor } \\
(10 \text { thousand } \\
\text { people })\end{array}$ & $\begin{array}{c}\text { Capital } \\
(100 \text { million } \\
\text { yuan })\end{array}$ & $\begin{array}{c}\text { Energy } \\
\text { (Standard coal })\end{array}$ & $\begin{array}{c}\text { Industrial add value } \\
(100 \text { million yuan })\end{array}$ & $\begin{array}{c}\mathrm{CO}_{2} \text { emission } \\
(100 \text { million } \\
\left.\text { tonnes } \mathrm{CO}_{2}\right)\end{array}$ \\
\hline Mean & 229.63 & 1035.78 & 4796.11 & 3515.55 & 152.59 \\
\hline Median & 130.44 & 670.17 & 1356.64 & 1774.49 & 16.88 \\
\hline Maximum & 926.60 & 8860.38 & 39544.25 & 24370.20 & 2144.19 \\
\hline Minimum & 0.21 & 4.08 & 34.98 & 2.70 & 0.30 \\
\hline Standard Deviation & 213.26 & 1635.18 & 8037.36 & 5244.39 & 398.05 \\
\hline Skewness & 1.33 & 3.73 & 2.77 & 2.88 & 3.87 \\
\hline Kurtosis & 1.74 & 15.16 & 8.44 & 8.88 & 16.32 \\
\hline
\end{tabular}


Table 5. Spearman's rank correlation for inputs and outputs of 42 industrial sectors.

\begin{tabular}{|c|c|c|c|}
\hline & Labor & Capital & Energy \\
\hline Industrial added value & $0.827^{* *}(0.000)$ & $0.848^{* *}(0.000)$ & $0.776^{* *}(0.000)$ \\
\hline $\mathrm{CO}_{2}$ emissions & $0.539^{* *}(0.000)$ & $0.788^{* *}(0.000)$ & $0.940^{* *}(0.000)$ \\
\hline
\end{tabular}

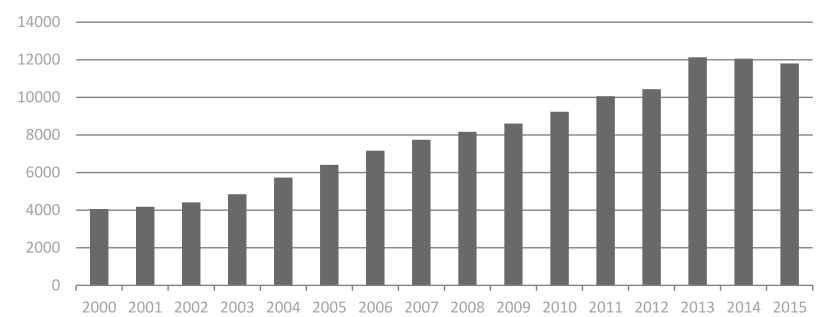

Fig. 1. Total $\mathrm{CO}_{2}$ emissions in 42 industries from 2005 to 2015 .

According to Eq. 1., we calculated the total of $\mathrm{CO}_{2}$ emissions from 2000 to 2015 (as presented in Fig. 1). Meanwhile, based on the super-SBM models analysis mentioned above, we can obtain the $\mathrm{CO}_{2}$ emission efficiency of 42 industrial sectors. Obviously, there exist distinct differences in terms of $\mathrm{CO}_{2}$ emissions efficiency among various industrial sectors. As can be seen from Fig. 2, other mining industry and manufacturing of waste resources and materials recycling and processing have the highest $\mathrm{CO}_{2}$ emissions efficiencies, which ranged from 1 to 1.8 from 2005 to 2015. Additionally, almost all of agriculture, forestry, the fishery industry, tobacco manufacturing, wholesale, retail, accommodation and catering, manufacturing of metal products, and the construction industry are more than 1 , except for a few years. Thus, in comparison with others, these industrial sectors have reached the frontier of production, relatively more advanced technology, and less pollution.

Some studies suggest that in the process of efficiency evaluation, by adjusting input and output variables, the efficiency of carbon dioxide emissions will increase to 1 , which will be optimized. It can be seen that the carbon dioxide emission efficiency has a close relationship with the output. However, it is not accurate to assign the responsibility only through the efficiency of carbon dioxide emissions during the distribution of emissions. Inefficient industries should certainly undertake larger emission tasks. However, in the process of carbon allowance allocation, the description of efficiency indicator is not comprehensive, which means that in order to make the allowance more equitable and reasonable, we should take into consideration multiple indicators.

\section{Comparative Analysis of Multiple Indicators}

\section{Characterization of Equal Weighting}

Under the equal weighting case, we assign the reduction burden according to the indicator values for capacity, responsibility, and potential equally (see Fig. 3.). According to the allocation results, the 42 industrial sectors can be divided into four categories of high, medium high, medium, and low reduction burdens. The first category contains four industrial sectors, whose intensity reduction burdens are more than $65 \%$. The second and third categories contain 10 industrial sectors with intensity reduction burdens from $65 \%$ to $50 \%$ and 18 industrial sectors with intensity reduction burdens from $50 \%$ to $35 \%$, respectively. The fourth category contains three industrial sectors, whose intensity reduction burdens are less than $35 \%$.

We make a comparison of the four categories and analysis the characteristics by integrating the indicators. Manufacturing of oil processing, coking, nuclear fuels processing, smelting and the rolling process of ferrous metal, manufacturing of non-metal products, ferrous

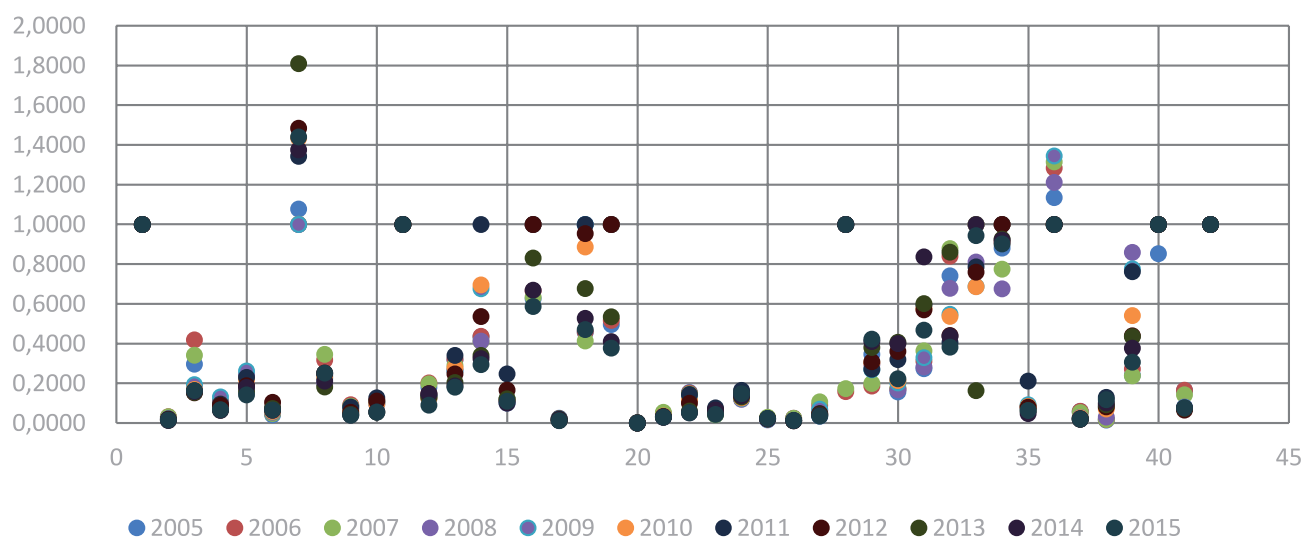

Fig. 2. $\mathrm{CO}_{2}$ efficiencies of 42 industrial sectors in 2005-2015 in China. 


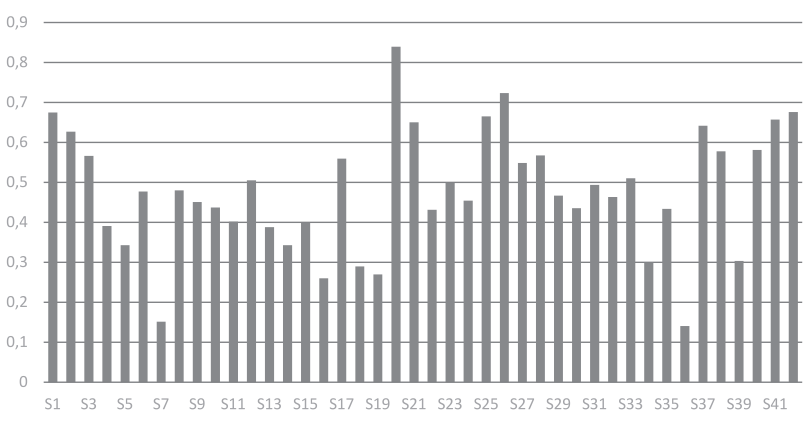

Fig. 3. Carbon intensity reduction burdens in 2030 under the equal weighting case.

metal, manufacturing of raw chemical materials and chemical products, transportation, storage, and postal service are with higher accumulated $\mathrm{CO}_{2}$ emissions and industrial value added. However, lower values of $\mathrm{CO}_{2}$ emissions efficiency, in particular wholesale, retail, accommodation, and catering have highest industrial value added, but the value of $\mathrm{CO}_{2}$ emissions efficiency is 1 from 2005-2015. In the second category, production and supply of electricity, heat, gas and water, coal mining and washing, construction industry, manufacturing metal products, oil and natural gas mining, smelting and rolling process of non-ferrous metal, and the manufacutre of communication devices, computers, and other electronic devices and textile manufacturing have high accumulated $\mathrm{CO}_{2}$ emissions and industrial value added, whereas the production and distribution of gas, paper making, and paper products manufacturing, and the manufacture of chemical fibers all have low values for industrial value added. Specifically, manufacturing metal products and the construction industry with the value of $\mathrm{CO}_{2}$ emissions efficiency is 1 , while all of the industrial sectors in the third category have low accumulated $\mathrm{CO}_{2}$ emissions, industrial value added, and high $\mathrm{CO}_{2}^{2}$ emissions efficiency. In contrast with the first three categories, the accumulated $\mathrm{CO}_{2}$ emissions and industrial value added are the lowest of the fourth category, and other mining industry, furniture manufacturing, manufacturing of instruments, cultural and official mechanics, and handicrafts and other manufacturing have higher $\mathrm{CO}_{2}$ emissions efficiency, though the value of nonferrous metal mining, leather, fur, feather, and related products manufacturing, printing, and record medium reproduction manufacturing, cultural, educational, and sports goods manufacturing and production and distribution of water range from 0.14 to 1 . In contrast, this is higher than most of the industrial sector in the first three categories.

According to the results above, it is can be concluded that an industrial sector with high indicators of historical accumulated emissions and carbon intensity will shoulder more intensity reduction burden. Thus, the industrial sector with the heaviest reduction burdens are those with two high indicators for the equal weighting case.

\section{Characterization of Preferred Responsibility Case}

Fig. 4 shows that manufacturing of oil processing, coking, and nuclear fuels processing, wholesale, retail, accommodation and catering, agriculture, forestry, the fishery industry, smelting, and rolling process of ferrous metal, transportation, storage and postal service, manufacturing of non-metal products ferrous metal, manufacturing of raw chemical materials and chemical products, and production and supply of electricity, heat, gas and water assumed greater responsibility for emission reduction. The main characteristics of these industries are: high energy consumption, low $\mathrm{CO}_{2}$ emission efficiency, and high historical accumulated emission. In the process of China's economic development, various industries have to coordinate the relationship between their own development and environmental protection, rationally utilize resources, reduce energy consumption, and improve energy efficiency targets. Hence, industrial structure adjustment is an important strategy. On the one hand, the adjustment and establishment of a reasonable industrial structure can promote economic and social development, and on the other hand, it can adapt the industry to the change of market demand. To adjust industrial structure unreasonable industry, make the coordinated development of various industry departments, and provide products, services, and employment opportunities for social needs. At the same time, applying advanced industrial technology can obtain the best economic benefits.

\section{Characterization of Preferring Capacity Case}

Compared with equal case, the responsibility for reducing emissions of Other Mining industries comes into the first category. The main reason is that the industrial added value of other mining industry rank high in the 42 industrial sectors. This confirms the assumption that industries with more added value must be more capable of reducing emissions, and the feasibility of reducing emissions will be higher. At the same time, our country has set up a carbon trading market under which companies will be assigned an emissions quota and will be able to profit from selling excess permits to other firms if they are below their

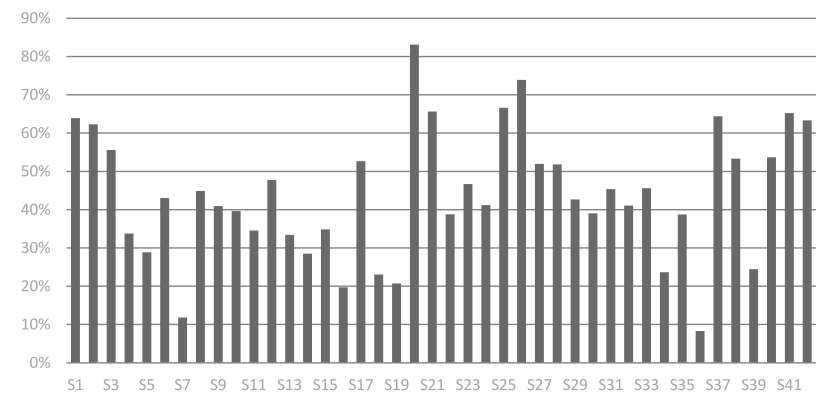

Fig. 4. Carbon intensity reduction burdens in 2030 under the preferring responsibility case. 


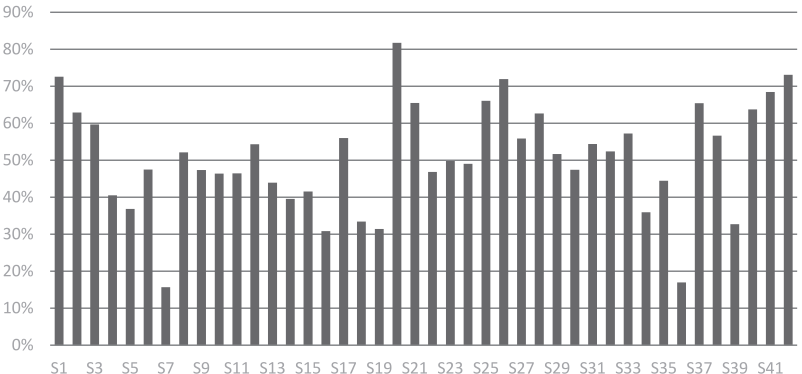

Fig. 5. Carbon intensity reduction burdens in 2030 under the preferred capacity case.

quota. In the process of pilot exploration, we should gradually establish a sound methodology system, and foster more third-party certification bodies, and establish a nationwide registration system. We should explore the formation of an emission rights distribution system, price formation system, and emission reduction incentive system (Fig. 5).

\section{Characterization of Preferring Potential Case}

The results in Fig. 6 show that the responsibility of leather, fur, feather, and related products manufacturing, production and distribution of water, printing and record medium reproduction manufacturing, manufacturing instruments, cultural and official mechanics, cultural, educational and sports goods manufacturing, furniture manufacturing, other mining industry and manufacturing of waste resources and materials recycling and processing emissions responsibility is low. The main reason is that these industries in aspects such as human resources and energy input is less, and the phenomenon is mainly related to the social demand. But it does not mean that the industry contribution rate of carbon dioxide is very low, and does not need to control and develop policies. China is in industrialization accelerate process, the manufacturing industry is the main power of economic growth, most of these industries belong to the second industry, the overall sustainable development of the economy is at a low profit, under powered industry chain at the bottom. Based on this, we should further promote the marketization of energy prices on the

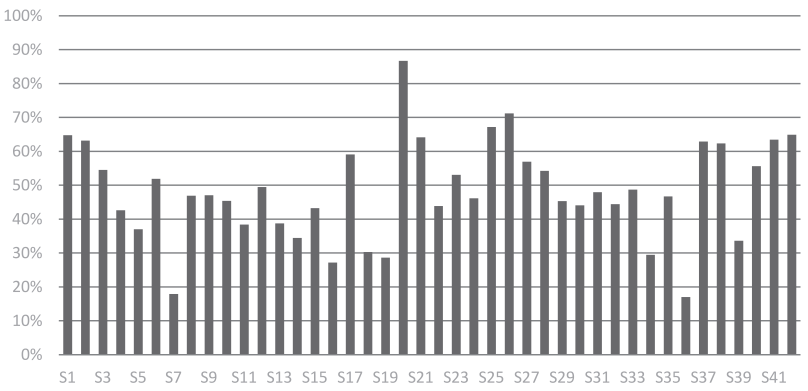

Fig. 6. Carbon intensity reduction burdens in 2030 under the preferred potential case.

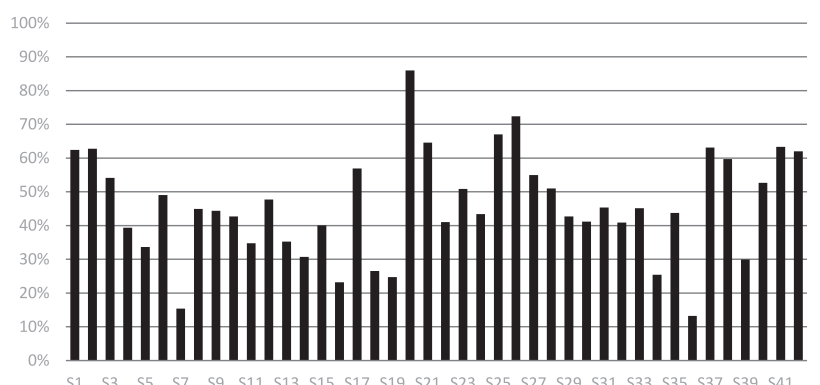

Fig. 7. Carbon intensity reduction burdens in 2030 under entropy weighting.

basis of fully considering economic affordability while taking into account the role of structural adjustment and technological progress.

\section{Characterization of Entropy Method Case}

In summary, in the process of contrasting allocation system, it is of vital importance to incorporate equity and fairness as well as select appropriate indicator selection, considering the industrial sector's actual situation and development status. Hence, in order to eliminate the influence of different preferences on the distribution results, this paper uses the allocation model based on entropy method to make a comparison. The entropy method is a kind of objective weighting method. It makes use of the inhomogeneity of data itself to reflect the importance of indicators, and gives an objective weight to allocate the carbon quotas more accurately. Compared to the allocation method based on equal weights, the allocation results based on entropy method seems more reasonable. The result in Fig. 7 further proves the conclusion that the industrial sector with high indicators of $\mathrm{CO}_{2}$ accumulated emission will shoulder more reduction burden.

\section{Conclusions}

By building a carbon intensity distribution model, this paper allocated China's national responsibility distribution among the various industries. Based on the results, the main conclusions and policy suggestions are as follows:

1) Research has shown that the $\mathrm{CO}_{2}$ emissions efficiency of manufacturing of oil processing, coking and nuclear fuels processing, manufacturing of non-metal products ferrous metal and smelting and rolling process of ferrous metal is lower from 2005 to 2015. The reason is that the cumulative carbon dioxide emissions of these industries are higher, while the added value of the industry is lower, resulting in lower $\mathrm{CO}_{2}$ emission efficiency, and has not shown a convergence trend. Furthermore, they are typical energy-intensive and highly polluting industries, and therefore the input and output is unreasonable. 
In summary, it is required to pay more attention to adjusting industrial structure, controlling production, and developing such industry.

2) Under multiple indicators, whatever the inclination of policy makers, manufacturing of oil processing, coking, and nuclear fuels processing and smelting and rolling process of ferrous metal are assigned more carbon dioxide intensity reduction burden, at more than $70 \%$. The comment of those industries is that they have at least two higher indicators. In addition, the tendency of decision makers on different allocation principles has a great impact on the distribution of emission reduction responsibility in some industries, particularly in leather, fur, feather and related products manufacturing, and the manufacture of instruments, cultural, and official mechanics. They all exhibit a common characteristic in that the gap between preferring potential case and preferring capacity case is over $10 \%$. This study demonstrates that these industries require less input but have stronger economic capacity. Therefore, their responsibilities are reduced when the decision maker is biased toward the capacity case.

In the future, the state mandatory reduction internal responsibility can be conducted at a regional perspective, and the allocation of the regional can also start from the industry perspective. When assigning responsibility for carbon dioxide emission reduction in various industries, it is not only necessary to consider the efficiency of energy consumption or carbon dioxide emission, but also the fairness and feasibility principle of the distribution scheme.

Appendix A. Industry code and names of 42 sub-industries.

\begin{tabular}{|c|c|c|}
\hline Industry structure & $\begin{array}{l}\text { Industry } \\
\text { code }\end{array}$ & Industry name \\
\hline Primary industry & $\mathrm{S} 1$ & Agriculture, forestry, fishery and fishery industry \\
\hline \multirow[t]{25}{*}{ Secondary industry } & S2 & Coal mining and washing \\
\hline & $\mathrm{S} 3$ & Oil and natural gas mining \\
\hline & S4 & Ferrous metal mining \\
\hline & S5 & Non-ferrous metal mining \\
\hline & S6 & Non-metal mining \\
\hline & S7 & Other Mining industry \\
\hline & S8 & Agricultural products processing \\
\hline & S9 & Food manufacturing \\
\hline & $\mathrm{S} 10$ & Wine, beverage, and refined tea manufacturing \\
\hline & S11 & Tobacco manufacturing \\
\hline & $\mathrm{S} 12$ & Textile manufacturing \\
\hline & S13 & Textile clothing and leather products manufacturing \\
\hline & S14 & Leather, fur, feather, and related products manufacturing \\
\hline & S15 & Wood processing and wood, bamboo, cane, palm, and straw manufacturing \\
\hline & S16 & Furniture manufacturing \\
\hline & S17 & Paper making and paper products manufacturing \\
\hline & S18 & Printing and record medium reproduction manufacturing \\
\hline & S19 & Cultural, educational, and sports goods manufacturing \\
\hline & S20 & Manufacturing of oil processing, coking, and nuclear fuels processing \\
\hline & $\mathrm{S} 21$ & Manufacturing of raw chemical materials and chemical products \\
\hline & S22 & Manufacturing of medicine \\
\hline & $\mathrm{S} 23$ & Manufacturing of chemical fibers \\
\hline & S24 & Manufacturing of rubber and plastic \\
\hline & S25 & Manufacturing of non-metal products ferrous metal \\
\hline & $\mathrm{S} 26$ & Smelting and rolling process of ferrous metal \\
\hline
\end{tabular}


Appendix A. Continued.

\begin{tabular}{|c|c|c|}
\hline & S27 & Smelting and rolling process of non-ferrous metal \\
\hline & S28 & Manufacturing of metal products \\
\hline & S29 & Manufacturing of ordinary machinery \\
\hline & S30 & Manufacturing of special equipment \\
\hline & S31 & Manufacture of transport equipment \\
\hline & S32 & Manufacturing of electrical machinery and equipment \\
\hline & S33 & Manufacturing of communication device, computers, and other electronics \\
\hline & S34 & Manufacturing of instruments, cultural, and official mechanics \\
\hline & S35 & Handicrafts and other manufacturing \\
\hline & S36 & Manufacturing of waste resources and materials recycling and processing \\
\hline & S37 & Production and supply of electricity, heat, gas, and water \\
\hline & $\mathrm{S} 38$ & Production and distribution of gas \\
\hline & S39 & Production and distribution of water \\
\hline & S40 & Construction industry \\
\hline \multirow[t]{2}{*}{ Tertiary industry } & S41 & Transportation, storage, and postal service \\
\hline & S42 & Wholesale, retail, accommodation and catering \\
\hline
\end{tabular}

Appendix B. Indicator values of 42 industrial sectors in China.

\begin{tabular}{|c|c|c|c|}
\hline & $\begin{array}{l}\text { Accumulated } \mathrm{CO}_{2} \text { emissions } 2000-2005 \\
\left(100 \text { million tons } \mathrm{CO}_{2}\right)\end{array}$ & $\begin{array}{l}\text { Industrial added value } 2005 \\
\text { (100 million yuan) }\end{array}$ & $\mathrm{CO}_{2}$ emission efficiency 2005 \\
\hline S1 & 495. 5069615 & 22420 & 1. 0000 \\
\hline S2 & 1259.532786 & 2888.25 & 0.0279 \\
\hline S3 & 687.7858025 & 4813.96 & 0.2970 \\
\hline S4 & 32. 74280622 & 426.5 & 0.1034 \\
\hline S5 & 24. 9014186 & 427.6 & 0.1906 \\
\hline S6 & 83. 26692956 & 280.51 & 0.0418 \\
\hline S7 & 17. 37618636 & 2.7 & 1. 0779 \\
\hline S8 & 193. 2188871 & 2745.96 & 0.2398 \\
\hline S9 & 100. 669119 & 1168.32 & 0.0872 \\
\hline S10 & 92.5933201 & 1164.73 & 0.1080 \\
\hline S11 & 23.76823136 & 2059.99 & 1. 0000 \\
\hline $\mathrm{S} 12$ & 261.0902628 & 3240.19 & 0.1809 \\
\hline S13 & 29.31000493 & 1419.86 & 0.3182 \\
\hline S14 & 17. 01643681 & 944.38 & 0.4347 \\
\hline S15 & 40.30841332 & 510.86 & 0.1013 \\
\hline S16 & 7. 648840279 & 384.87 & 0.6260 \\
\hline S17 & 300.2265295 & 1146. 4 & 0.0250 \\
\hline S18 & 12. 6969378 & 463. 06 & 0.4573 \\
\hline S19 & 8. 092975757 & 379.71 & 0.4966 \\
\hline S20 & 5220.298386 & 1981.64 & 0.0022 \\
\hline S21 & 1892. 572891 & 4391.92 & 0.0426 \\
\hline
\end{tabular}


Appendix B. Continued.

\begin{tabular}{|c|c|c|c|}
\hline S22 & 79. 32774534 & 1529.8 & 0.1545 \\
\hline S23 & 208. 5913414 & 485.31 & 0.0427 \\
\hline S24 & 95.85621336 & 1867.41 & 0.1257 \\
\hline S25 & 1866.004715 & 2807.92 & 0.0187 \\
\hline S26 & 4054. 736927 & 5776.9 & 0.0243 \\
\hline S27 & 327.7799565 & 1929.65 & 0.0352 \\
\hline S28 & 84. 58119696 & 9399.93 & 1. 0000 \\
\hline S29 & 117.0269451 & 2966.96 & 0.3467 \\
\hline $\mathrm{S} 30$ & 75.32512582 & 1681.56 & 0.1574 \\
\hline S31 & 136. 5902495 & 3830.52 & 0.2743 \\
\hline S32 & 43. 91364417 & 3574.13 & 0.7418 \\
\hline S33 & 38. 2120619 & 5722.11 & 1. 0000 \\
\hline S34 & 8. 58559633 & 733.19 & 0.8814 \\
\hline S35 & 67.92108905 & 570.83 & 0.0742 \\
\hline S36 & 6. 440059813 & 59.93 & 1. 1355 \\
\hline S37 & 1624.831648 & 5719.79 & 0.0592 \\
\hline $\mathrm{S} 38$ & 149. 2793822 & 134. 52 & 0.0157 \\
\hline S39 & 13. 59950593 & 261.64 & 0.2413 \\
\hline S40 & 159. 5570365 & 10133.8 & 0.8532 \\
\hline S41 & 1535. 179009 & 10835.7 & 0.1651 \\
\hline S42 & 245.4708954 & 24370.2 & 1. 0000 \\
\hline
\end{tabular}

(Dates are from the China Statistical Yearbook from 2000 to 2005)

Appendix C. Intensity reduction burdens for 42 industrial sectors under the eight cases.

\begin{tabular}{|c|c|c|c|c|}
\hline & Case 1 & Case 2 & Case 3 & Case4 \\
\hline S1 & $67 \%$ & $64 \%$ & $73 \%$ & $65 \%$ \\
\hline S2 & $63 \%$ & $62 \%$ & $63 \%$ & $63 \%$ \\
\hline S3 & $57 \%$ & $56 \%$ & $60 \%$ & $55 \%$ \\
\hline S4 & $39 \%$ & $34 \%$ & $41 \%$ & $43 \%$ \\
\hline S5 & $34 \%$ & $29 \%$ & $37 \%$ & $37 \%$ \\
\hline S6 & $48 \%$ & $43 \%$ & $47 \%$ & $52 \%$ \\
\hline S7 & $15 \%$ & $12 \%$ & $16 \%$ & $18 \%$ \\
\hline S8 & $48 \%$ & $45 \%$ & $52 \%$ & $47 \%$ \\
\hline S9 & $45 \%$ & $41 \%$ & $47 \%$ & $47 \%$ \\
\hline S10 & $44 \%$ & $40 \%$ & $46 \%$ & $45 \%$ \\
\hline S11 & $40 \%$ & $35 \%$ & $46 \%$ & $38 \%$ \\
\hline S12 & $51 \%$ & $48 \%$ & $54 \%$ & $49 \%$ \\
\hline S13 & $39 \%$ & $33 \%$ & $44 \%$ & $39 \%$ \\
\hline S14 & $34 \%$ & $28 \%$ & $40 \%$ & $34 \%$ \\
\hline S15 & $40 \%$ & $35 \%$ & $42 \%$ & $43 \%$ \\
\hline
\end{tabular}

\begin{tabular}{|l|l|l|l|l|}
\hline S16 & $26 \%$ & $20 \%$ & $31 \%$ & $27 \%$ \\
\hline S17 & $56 \%$ & $53 \%$ & $56 \%$ & $59 \%$ \\
\hline S18 & $29 \%$ & $23 \%$ & $33 \%$ & $30 \%$ \\
\hline S19 & $27 \%$ & $21 \%$ & $31 \%$ & $29 \%$ \\
\hline S20 & $84 \%$ & $83 \%$ & $82 \%$ & $87 \%$ \\
\hline S21 & $65 \%$ & $66 \%$ & $65 \%$ & $64 \%$ \\
\hline S22 & $43 \%$ & $39 \%$ & $47 \%$ & $44 \%$ \\
\hline S23 & $50 \%$ & $47 \%$ & $50 \%$ & $53 \%$ \\
\hline S24 & $45 \%$ & $41 \%$ & $49 \%$ & $46 \%$ \\
\hline S25 & $67 \%$ & $67 \%$ & $66 \%$ & $67 \%$ \\
\hline S26 & $72 \%$ & $74 \%$ & $72 \%$ & $71 \%$ \\
\hline S27 & $55 \%$ & $52 \%$ & $56 \%$ & $57 \%$ \\
\hline S28 & $57 \%$ & $52 \%$ & $63 \%$ & $54 \%$ \\
\hline S29 & $47 \%$ & $43 \%$ & $52 \%$ & $45 \%$ \\
\hline S30 & $44 \%$ & $39 \%$ & $47 \%$ & $44 \%$ \\
\hline S31 & $49 \%$ & $45 \%$ & $54 \%$ & $48 \%$ \\
\hline
\end{tabular}


Appendix C. Continued.

\begin{tabular}{|c|c|c|c|c|}
\hline S32 & $46 \%$ & $41 \%$ & $52 \%$ & $44 \%$ \\
\hline S33 & $51 \%$ & $46 \%$ & $57 \%$ & $49 \%$ \\
\hline S34 & $30 \%$ & $24 \%$ & $36 \%$ & $29 \%$ \\
\hline S35 & $43 \%$ & $39 \%$ & $44 \%$ & $47 \%$ \\
\hline S36 & $14 \%$ & $8 \%$ & $17 \%$ & $17 \%$ \\
\hline S37 & $64 \%$ & $64 \%$ & $65 \%$ & $63 \%$ \\
\hline
\end{tabular}

\begin{tabular}{|l|l|l|l|l|}
\hline S38 & $58 \%$ & $53 \%$ & $57 \%$ & $62 \%$ \\
\hline S39 & $30 \%$ & $24 \%$ & $33 \%$ & $34 \%$ \\
\hline S40 & $58 \%$ & $54 \%$ & $64 \%$ & $56 \%$ \\
\hline S41 & $66 \%$ & $65 \%$ & $68 \%$ & $63 \%$ \\
\hline S42 & $68 \%$ & $63 \%$ & $73 \%$ & $65 \%$ \\
\hline
\end{tabular}

Appendix D. The industrial $\mathrm{CO}_{2}$ emissions efficiencies in China's 42 industrial sectors.

\begin{tabular}{|c|c|c|c|c|c|c|c|c|c|c|c|}
\hline & 2005 & 2006 & 2007 & 2008 & 2009 & 2010 & 2011 & 2012 & 2013 & 2014 & 2015 \\
\hline S1 & 1.0000 & 1.0000 & 1.0000 & 1. 0000 & 1. 0000 & 1. 0000 & 1. 0000 & 1. 0000 & 1.0000 & 1. 0000 & 1. 0000 \\
\hline $\mathrm{S} 2$ & 0.0279 & 0.0325 & 0.0324 & 0.0223 & 0.0209 & 0.0201 & 0.0211 & 0.0189 & 0.0145 & 0.0138 & 0.0165 \\
\hline S3 & 0.2970 & 0.4194 & 0.3421 & 0.1856 & 0.1940 & 0.1701 & 0.1627 & 0.1529 & 0.1550 & 0.1592 & 0.1642 \\
\hline S4 & 0.1034 & 0.1100 & 0.1102 & 0.1056 & 0.1322 & 0.0960 & 0.0966 & 0.0898 & 0.0655 & 0.0645 & 0.0678 \\
\hline S5 & 0.1906 & 0.2356 & 0.2301 & 0.2433 & 0.2628 & 0.2192 & 0.2306 & 0.1886 & 0.1595 & 0.1801 & 0.1424 \\
\hline S6 & 0.0418 & 0.0521 & 0.0488 & 0.0551 & 0.0589 & 0.0595 & 0.0764 & 0.1050 & 0.0737 & 0.0646 & 0.0665 \\
\hline S7 & 1. 0779 & 1.0000 & 1.0014 & 1.0000 & 1.0000 & 1. 4350 & 1. 3432 & 1. 4848 & 1. 8098 & 1. 3758 & 1. 4408 \\
\hline S8 & 0.2398 & 0.3180 & 0.3465 & 0.1985 & 0.2247 & 0.2322 & 0.2497 & 0.2522 & 0.1823 & 0.2119 & 0.2523 \\
\hline S9 & 0.0872 & 0.0928 & 0.0852 & 0.0720 & 0.0725 & 0.0605 & 0.0813 & 0.0548 & 0.0443 & 0.0411 & 0.0401 \\
\hline S10 & 0.1080 & 0.1151 & 0.1096 & 0.0956 & 0.1005 & 0.0976 & 0.1275 & 0.1115 & 0.0556 & 0.0567 & 0.0554 \\
\hline S11 & 1.0000 & 1.0000 & 1.0000 & 1.0000 & 1.0000 & 1.0000 & 1.0000 & 1.0000 & 1.0000 & 1.0000 & 1. 0000 \\
\hline S12 & 0.1809 & 0. 2027 & 0. 1979 & 0.1253 & 0.1347 & 0.1253 & 0.1404 & 0.1493 & 0.1304 & 0.1473 & 0.0907 \\
\hline $\mathrm{S} 13$ & 0.3182 & 0.3229 & 0. 2904 & 0.2686 & 0.2638 & 0.2784 & 0.3412 & 0.2480 & 0.2047 & 0.1874 & 0.1812 \\
\hline S14 & 0.4347 & 0.4373 & 0.4109 & 0.4130 & 0.6767 & 0.6958 & 1.0000 & 0.5368 & 0.3410 & 0.3249 & 0. 2948 \\
\hline S15 & 0.1013 & 0.1179 & 0.1224 & 0.1150 & 0.1228 & 0.1183 & 0.2480 & 0.1667 & 0.1226 & 0.1010 & 0.1105 \\
\hline S16 & 0.6260 & 0.6662 & 0.6342 & 1.0000 & 1. 0000 & 1.0000 & 1.0000 & 1.0000 & 0.8313 & 0.6693 & 0.5873 \\
\hline S17 & 0.0250 & 0.0237 & 0.0224 & 0.0206 & 0.0198 & 0.0177 & 0.0218 & 0.0158 & 0.0141 & 0.0142 & 0.0128 \\
\hline S18 & 0.4573 & 0.4609 & 0.4139 & 1.0000 & 1.0000 & 0.8870 & 1.0000 & 0.9543 & 0.6776 & 0.5278 & 0.4712 \\
\hline S19 & 0.4966 & 0.5174 & 1. 0000 & 1.0000 & 1.0000 & 1. 0000 & 1.0000 & 1.0000 & 0.5354 & 0.4106 & 0.3780 \\
\hline S20 & 0.0022 & 0.0019 & 0.0023 & 0.0016 & 0.0014 & 0.0011 & 0.0013 & 0.0008 & 0.0007 & 0.0006 & 0.0005 \\
\hline S21 & 0.0426 & 0.0495 & 0.0546 & 0.0293 & 0.0338 & 0.0360 & 0.0337 & 0.0327 & 0.0303 & 0.0304 & 0.0305 \\
\hline S22 & 0.1545 & 0.1519 & 0.1470 & 0.1270 & 0.1271 & 0.1163 & 0.1445 & 0.1004 & 0.0609 & 0.0520 & 0.0523 \\
\hline S23 & 0.0427 & 0.0458 & 0.0422 & 0.0519 & 0.0611 & 0.0680 & 0.0770 & 0.0644 & 0.0487 & 0.0660 & 0.0442 \\
\hline S24 & 0.1257 & 0.1326 & 0.1589 & 0.1200 & 0.1243 & 0.1273 & 0.1652 & 0.1434 & 0.1320 & 0.1382 & 0.1483 \\
\hline S25 & 0.0187 & 0.0259 & 0.0297 & 0.0166 & 0.0185 & 0.0214 & 0.0227 & 0.0226 & 0.0217 & 0.0210 & 0.0243 \\
\hline S26 & 0.0243 & 0.0247 & 0.0245 & 0.0144 & 0.0145 & 0.0137 & 0.0124 & 0.0122 & 0.0126 & 0.0127 & 0.0138 \\
\hline S27 & 0.0352 & 0.0904 & 0. 1074 & 0.0642 & 0.0705 & 0.0482 & 0.0489 & 0.0451 & 0.0419 & 0.0389 & 0.0358 \\
\hline S28 & 1. 0000 & 0.1589 & 0.1739 & 1. 0000 & 1.0000 & 1. 0000 & 1. 0000 & 1. 0000 & 1. 0000 & 1. 0000 & 1.0000 \\
\hline S29 & 0.3467 & 0.1869 & 0. 1999 & 0.2952 & 0. 2688 & 0.3033 & 0.2720 & 0.3094 & 0.3811 & 0.4110 & 0.4230 \\
\hline $\mathrm{S} 30$ & 0.1574 & 0.1725 & 0.1764 & 0.1684 & 0. 2025 & 0.2146 & 0.3202 & 0.3614 & 0.4072 & 0.4006 & 0.2236 \\
\hline S31 & 0. 2743 & 0.3117 & 0.3642 & 0.2834 & 0.3297 & 0.5769 & 0.5941 & 0.5705 & 0.6018 & 0.8371 & 0.4683 \\
\hline
\end{tabular}


Appendix D. Continued

\begin{tabular}{|l|l|l|l|l|l|l|l|l|l|l|l|}
\hline S32 & 0.7418 & 0.8407 & 0.8788 & 0.6789 & 0.5481 & 0.5377 & 0.4058 & 0.4414 & 0.8608 & 0.4375 & 0.3828 \\
\hline S33 & 1.0000 & 1.0000 & 1.0000 & 0.8113 & 0.6881 & 0.6871 & 0.7868 & 0.7603 & 0.1639 & 1.0000 & 0.9441 \\
\hline S34 & 0.8814 & 0.9101 & 0.7754 & 0.6762 & 1.0000 & 1.0000 & 1.0000 & 1.0000 & 0.9265 & 0.9215 & 0.9023 \\
\hline S35 & 0.0742 & 0.0829 & 0.0852 & 0.0854 & 0.0927 & 0.0841 & 0.2120 & 0.0805 & 0.0634 & 0.0483 & 0.0637 \\
\hline S36 & 1.1355 & 1.2842 & 1.3154 & 1.2120 & 1.3450 & 1.0000 & 1.0000 & 1.0000 & 1.0000 & 1.0000 & 1.0000 \\
\hline S37 & 0.0592 & 0.0599 & 0.0534 & 0.0291 & 0.0277 & 0.0274 & 0.0234 & 0.0200 & 0.0210 & 0.0202 & 0.0202 \\
\hline S38 & 0.0157 & 0.0183 & 0.0188 & 0.0308 & 0.0814 & 0.0716 & 0.1300 & 0.0823 & 0.0926 & 0.1015 & 0.1183 \\
\hline S39 & 0.2413 & 0.2726 & 0.2384 & 0.8598 & 0.7771 & 0.5417 & 0.7626 & 0.4398 & 0.4359 & 0.3777 & 0.3071 \\
\hline S40 & 0.8532 & 1.0000 & 1.0000 & 1.0000 & 1.0000 & 1.0000 & 1.0000 & 1.0000 & 1.0000 & 1.0000 & 1.0000 \\
\hline S41 & 0.1651 & 0.1661 & 0.1430 & 0.0813 & 0.0794 & 0.0749 & 0.0731 & 0.0660 & 0.0742 & 0.0771 & 0.0769 \\
\hline S42 & 1.0000 & 1.0000 & 1.0000 & 1.0000 & 1.0000 & 1.0000 & 1.0000 & 1.0000 & 1.0000 & 1.0000 & 1.0000 \\
\hline
\end{tabular}

This table is calculated by the model of Super-SBM. Labor capital stock, and energy are input factors, value-added of the industry is used as a sole desirable output and $\mathrm{CO}_{2}$ emission is used as an undesirable output. It indicates that the efficiency of undesired outputs can be calculated by the ratio of the undesired output value to the pre-optimal output value. Therefore, $\mathrm{CO}_{2}$ emissions efficiency is calculated by Eq. 3 .

\section{Acknowledgements}

Our current work is supported by the National Social Science Foundation of China (grant No. 15BGL145), the National Natural Science Foundation of China (No. 71471061), the Fundamental Research Funds for the Central Universities (No. 2016MS125), and the Philosophy and Social Science Research Base of Hebei Province.

\section{Conflict of Interest}

The authors declare no conflict of interest.

\section{References}

1. MIKAEL HÖÖK, XU TANG Depletion of fossil fuels and anthropogenic climate change-A review. Energy Policy 52, 797, 2013.

2. JESSE D. JENKINS. Political economy constraints on carbon pricing policies: What are the implications for economic efficiency, environmental efficacy, and climate policy design?. Energy Policy 69, 467, 2014.

3. HIDEKI FUKUI, CHIKAGE MIYOSHI The impact of aviation fuel tax on fuel consumption and carbon emissions:The case of the US airline industry. Transportation Research Part D 50, 234, 2017.

4. LIXU LI, YINA LI, FEI YE, LI ZHANG Carbon dioxide emissions quotas allocation in the Pearl River Delta region: Evidence from the maximum deviation method. Journal of Cleaner Production 177, 207, 2018.

5. Centre for International Climate and Environmental Research, 2017. CICERO. An interdisciplinary research centre for climate research and environmental science/ environmental studies in Oslo.Available online: $<$ https:// en.wikipedia.org/wiki/Centre_for_International_Climate_
and_Environme ntal_Research $>$.(accessed on 2017)

6. China's Intended Nationally Determined Contribution: Enhanced Actions on Climate Change. http://www4. unfecc. int/submissions/INDC/Submission Pages/ Submissions. aspx (accessed on 8 November 2016).

7. National Development and Reform Commission, 2017. NDRC. Notice of the national development and reform commission on the issuance of the national carbon emission trading market construction scheme (power generation industry). Climate change regulation. [2017] no. 2191. Available online: $<\mathrm{http} / / / \mathrm{www}$. chinasmartgrid. com. $\mathrm{cn} /$ news/20171221/626557. shtml $>$ (accessed on 2017)

8. XIANG JI, GUO, ZHAOHUA WANG Allocation of emission permits for China's power plants: A systemic Pareto optimal method. Applied Energy 204, 607, 2017.

9. YUJIE LU, XINYUAN ZHU, QINGBIN CUI Effectiveness and equity implications of carbon policies in the United States construction industry. Building and Environment 49, 259, 2012.

10. YING LIU, KANKESU JAYANTHAKUMARAN, FRANK NERI Who is responsible for the $\mathrm{CO}_{2}$ emissions that China produces?. Energy Policy 62, 1412, 2013.

11. HAILIN MU, HUANAN LI, MING ZHANG, MIAO LI Analysis of China's carbon dioxide flow for 2008. Energy Policy 54, 320, 2013.

12. CHRISTOPH B"HRINGER, KNUT EINAR Rosendahl Strategic partitioning of emission allowances under the EU Emission Trading Scheme. Resource and Energy Economics 31, 182, 2009.

13. BOQIANG LIN, HONGXUN LIU $\mathrm{CO}_{2}$ emissions of China's commercial and residential buildings: Evidence and reduction policy. Building and Environment 92, 418, 2015.

14. LING XIONG, BO SHEN, SHAOZHOU QI, LYNN PRICE, BIN YE The allowance mechanism of China's carbon trading pilots: A comparative analysis with schemes in EU and California. Applied Energy 185, 1849, 2017.

15. ZHOU P., WANG M. Carbon dioxide emissions allocation: A review. Ecological Economics 125, 47, 2016. 
16. YI-MING WEI, LE-LE ZOU, KAI WANG, WEN-JIN YI, LU WANG Review of proposals for an Agreement on Future Climate Policy: Perspectives from the responsibilities for GHG reduction. Energy Strategy Reviews 2, 161, 2013.

17. FENGCAI ZHAO, GANGYINLII, LAN GAO Establishing the fair allocation of international aviation carbon emission rights. Advances in Climate Change Research 5, 142, 2014

18. XUNZHANG PAN, FEI TENG A., YUEJIAO HA, GEHUA WANG Equitable Access to Sustainable Development:Based on the comparative study of carbon emission rights allocation schemes. Applied Energy 130, 632, 2014.

19. BAS J. VAN RUIJVENA, MATTHIAS WEITZEL, MICHEL G.J. DEN ELZEN, ANDRIES F. HOF, DETLEF P. VAN VUUREN, SONJA PETERSON, DAIJU NARITA Emission allowances and mitigation costs of China and India resulting from different effort-sharing approaches. Energy Policy 46, 116, 2012.

20. WEN-JING YI, LE-LE ZOU, JIE GUO, KAI WANG, YI-MING WEI How can China reach its $\mathrm{CO}_{2}$ intensity reduction targets by 2020? A regional allocation based on equity and development. Energy Policy 39, 2407, 2011.

21. HONGXUN LIU, BOQIANG LIN Cost-based modelling of optimal emission quota allocation. Journal of Cleaner Production 149, 472, 2017.

22. WENJIA CAI, CAN WANG, JINING CHEN Revisiting $\mathrm{CO}_{2}$ mitigation potential and costs in China's electricity sector. Energy Policy 38, 4209, 2010.

23. CHING CHIH CHANG, TIN CHIA LAI Carbon allowance allocation in the transportation industry. Energy Policy 63, 1091, 2013.

24. ROSE A. Reducing conflict in global warming policy: the potential of equity as a unifying principle. Energy Policy 18, 927, 1990.

25. LASSE RINGIUS, ASBJØRN TORVANGER, BJART HOLTSMARK Can multi-criteria rules fairly distribute climate burdens?. Energy Policy 26 (10), 777, 1998.

26. PHYLIPSEN G.J.M., BODE J.W., BLOK K. Department of Science. A Triptych sectoral approach to burden differentiation; GHG emissions in the European bubble. Energy Policy 26 (12), 929, 1998.

27. XUNZHANG PAN, FEI TENG, YALIN TIAN, GEHUA WANG Countries'emission allowances towards the low-carbon world:A consistent study. Applied Energy 155, 218, 2015.

28. CHRISTOPH BO HRINGER, ANDREAS LANGE On the design of optimal grandfathering schemes for emission allowances. European Economic Review 49, 2041, 2005.

29. SCHMIDT R.C., JOBST HEITZIG Carbon leakage: Grandfathering as an incentive device to avert firm relocation. Journal of Environmental Economics and Management 67, 209, 2014.

30. JINGNA JI, ZHIYONG ZHANG, LEI YANG Comparisons of initial carbon allowance allocation rules in an $\mathrm{O}_{2} \mathrm{O}$ retail supply chain with the cap-and-trade regulation. International Journal of Production Economics 187, 68, 2107.

31. MICHEL G.J. DEN ELZEN, NIKLAS, NIKLAS HÖHNE, BERND BROUNS, HARALD WINKLER, HERRMANN E. OTT Differentiation of countries'future commitments in apost-2012 climate regime An assessment of the 'South-North Dialogue' Proposal. Environmental Science \& Policy 10, 185, 2007.
32. JAEKYUN AHN Assessment of initial emission allowance allocation methods in the Korean electricity market. Energy Economics 43, 244, 2014.

33. XIAOLI ZHAO, HAITAO YIN, YUE ZHAO Impact of environmental regulations on the efficiency and $\mathrm{CO}_{2}$ emissions of power plants in China. Applied Energy 149, $238,2015$.

34. ZHUANG MIAO, YONG FENG, JICHUAN SHENG Efficient allocation of $\mathrm{CO}_{2}$ emissions in China: a zero sum gains data envelopment model. Journal of Cleaner Production 112, 4144, 2016.

35. BO MENG, JINJUN XUE, KUISHUANG FENG, DABO GUAN, XUE FU China's inter-regional spillover of carbon emissions and domestic supply chains. Energy Policy 61, 1305, 2013.

36. HAILIN MU, LINLIN LI, NAN LI, ZHAOQUAN XUE, LONGXI LI Allocation of carbon emission permits among industrial sectors in Liaoning province. Energy Procedia 104, 449, 2016.

37. ZHONGBAO ZHOU, CENJIE LIU, XIMEI ZENG, YONG JIANG, WENBIN LIU Carbon emission performance evaluation and allocation in Chinese cities. Journal of Cleaner Production 172, 1254, 2018.

38. HUANAN LI, YI-MING WEI, ZHIFU MI China's carbon flow: 2008-2012. Energy Policy 80, 45, 2015.

39. KE WANG, XIAN ZHANG, YI-MING WEI, SHIWEI YU Regional allocation of $\mathrm{CO}_{2}$ emissions allowance over provinces in China by 2020. Energy Policy 54, 214, 2013.

40. LINING WANG, DING MA, WENYING CHEN Future $\mathrm{CO}_{2}$ Emissions Allowances and Inequality Assessment under Different Allocation Regimes. Energy Procedia 61, 523, 2014

41. XUNZHANG PAN, FEI TENG A, YALIN TIAN, GEHUA WANG Countrie'emission allowances towards the low-carbon world:A consistent study. Applied Energy 155, 218, 2015.

42. XUNZHANG PAN, FEI TENG, GEHUA WANG Sharing emission space at an equitable basis: Allocation scheme based on the equal cumulative emission per capital principle. Applied Energy 113, 1810, 2014

43. RUI ZHAO, NING MIN, YONG GENG, YULONG HE Allocation of carbon emissions among industries/sectors: An emissions intensity reduction constrained approach. Journal of Cleaner Production 142, 3083, 2017.

44. JIARUI ZHANG, WEIHUA ZENG, JINNAN WANG, FENGLE YANG, HONGQIANG JIANG Regional lowcarbon economy efficiency in China: analysis based on the Super-SBM model with $\mathrm{CO}_{2}$ emissions. Journal of Cleaner Production 163, 202, 2017.

45. GUANGMING RAO, YONG WANG, KE LI, NA WANG Analysis on Chongqing Industry $\mathrm{CO}_{2}$ Emissions Efficiency Difference and Its Emissions Reduction Potentials. Energy Procedia, 2011.

46. YUE-JUN ZHANG, JUN-FANG HAO, JUAN SONG The $\mathrm{CO}_{2}$ emission efficiency, reduction potential and spatial clustering in China's industry: Evidence from the regional level. Applied Energy 174, 213, 2016.

47. JIANI ZHANG, JINGFANG XIAO, XIAOFANG CHEN, XIAOMING LIANG, LIYA FAN, DAIQI YE Allowance and allocation of industrial volatile organic compounds emission in China for year 2020 and 2030. Jourrnal of environment alsciences, JES-01328, No of Pages 11, 2017.

48. IPCC, 2006. Greenhouse Gas Inventory:IPCC Guidelines for National Greenhouse Gas Inventories. United Kingdom Meteorological Office, Bracknell, England. Lawrence Livermore National Laboratory, 2011. US Energy and 
Carbon Flow Chart. Available online: $</$ https://flowcharts. 1lnl. gov/index. html>.

49. JUAN WANG, TAO ZHAO, XIAOHU ZHANG Environmental assessment and investment strategies of provincial industrial sector in China-Analysis based on DEA model. Environmental Impact Assessment Review 60, 56, 2016.

50. HONG LI, JIN-FENG SHI Energy efficiency analysis on Chinese industrial sectors:an improved Super-SBM model with undesirable outputs. Journal of Cleaner Production 65, 97, 2014.

51. JIARUI ZHANG, WEIHUA ZENG, JINNAN WANG, FENGLE YANG, HONGQIANG JIANG Regional lowcarbon economy efficiency in China: analysis based on the Super-SBM model with $\mathrm{CO}_{2}$ emissions. Journal of Cleaner Production 163, 202, 2017.
52. TONE K.A. Slacks-based measure of super-efficiency in data envelopment analysis. European Journal of Operational Research 143 (1), 32, 2001.

53. HIROFUMI FUKUYAMA, WEBE W.L. A directional slacks-based measure of technical inefficiency. SocioEconomic Planning Sciences 43, 274, 2009.

54. TONE K., SAHOO B.K. Scale, indivisibilities and production function in data envelopment analysis. Int. J. Prod. Econ. 84, 165, 2003.

55. YUE-JUN ZHANG, JUN-FANG HAO, JUAN SONG The $\mathrm{CO}_{2}$ emission efficiency, reduction potential and spatial clustering in China's industry: Evidence from the regional level. Applied Energy 174, 213, 2016. 